\title{
Chess's game
}

It's a grey area.

\section{Nye Joell Hardy}

Ian Rodriguez rushed past his staff who were crawling across the labs' floors, looking under tables and lab equipment. $\mathrm{He}$ glared at a retinal scanner, which permitted him access to Lab 5.

Nothing had changed.

In the first glass enclosure, eight-week old tobianos - all fifth-generation clones - kitten-staggered through their food dishes. Each kitten was black and white. Specifically, their left sides were black and their right sides were white.

The next enclosure contained eight overos: three-month-old, second-generation clones. The kittens wrestled one another, ignoring him. Their vertical black and white stripes reminded Ian of old-fashioned prison uniforms.

The last enclosure belonged to Chess. Its glass door was agape. The cage was empty.

Each enclosure had an access panel, two-way retinal scanners and video surveillance. How did a thief get out of the lab unnoticed? Ian punched numbers into an intercom. "Dr Rodriguez here. I'm with the cancer cats. Pull video for GP Lab 5, Section 3, and send the feed to my office. The last 12 hours."

The cats were clones of an original 'foundation' cat, Sammy, but Ian's geneinsertion techniques controlled their coat colours. When Texas A\&M had started the cat-cloning business 20 years earlier, they could not have known what they had stumbled upon: mammalian blood vessels grew in random patterns, even in clones. In feline embryos, the blood's heat activated certain proteins in its fur, darkening it. If the vessels were close to the skin, the fur was black in that location. If the vessels were not, the fur remained white. This meant that a cat's coat colour showed where the blood vessels grew under the skin. Ian's cats' perfect patterns showed that his gene-insertions could control previously unpredictable vessel growth.

Cancer cells also grew in random patterns, just like blood vessels. Ian's gene therapies could be adapted to stop cancer growth, so Chess was the most important and expensive cat he'd ever made.

Ian returned to his office and reviewed the security footage. When he got to Chess's debut, he watched it twice: the door fell open by itself. Chess jumped down to the floor.

"A door malfunction?"
The cameras tracked only the activity of taller humans, so Chess was invisible on the floor. He was probably in the building, but no one knew where. Ian needed aspirin.

In the lunchroom, he could barely stand the laughter as he jammed coins into a vending machine.

"The world's not black and white, you know!"

"Sure it is! Zebras, pandas, orcas ..."

"... soccer balls..."

"Soccer balls aren't alive, you idiot."

Ian pulled two aspirins out of the machine and gulped them down

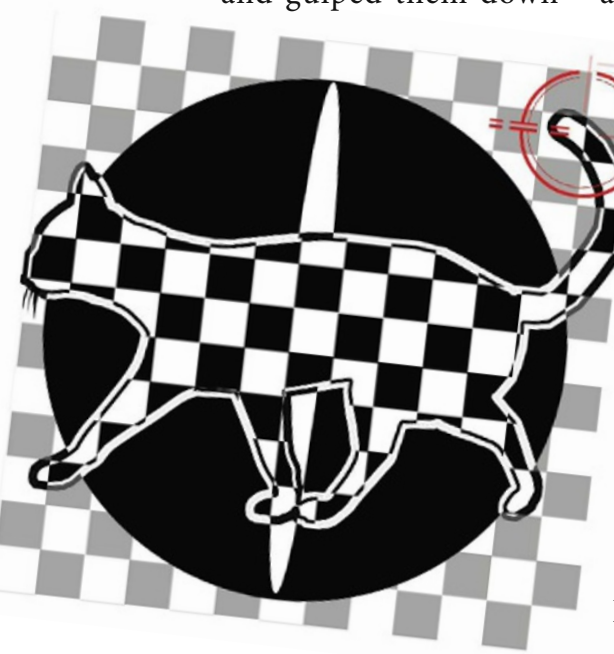

without water. Then

an unearthly screech made him choke.

Everyone was staring at the longest wall in the cafeteria. Again a wavering cry. Ian recognized the offended yowl of a Siamese cat.

His cat had escaped through a floor vent, climbed up into the duct work and then fallen through the wall. To the surprise of everyone in the lunchroom, Ian started kicking at the wall until he'd made a ragged hole.

Mid-wail, Chess fell silent. Worried, Ian backed away, waiting and listening.

A triangular head poked out from the wall. As the cat pulled out its lithe body, everyone fell silent.

Whiskers to fur to nails, a black-andwhite checkerboard blanketed the cat. Each square was 1.86 centimetres to a side. With pupils so dilated with rage that they eclipsed the bright blue irises, ears flat back against his head, and his long tail twitching a furious semaphore, Chess fast-slunk towards the corner. His short fur audibly brushed the wall.

Ian grabbed a lidded wastepaper basket, dumped the trash, and gave chase. As the cat reached the corner, Ian scooped him up, quickly righted the can, and replaced the lid.

Standing up, he grinned at the surprised employees.

A second escape couldn't be an accident.

Some time past midnight, Ian hustled past the guards. He was so nervous, it took three attempts to get past the retinal scanner.

It had to be sabotage.

In Lab 5, the tobianos wrestled one another. The overos stared at imaginary mice. Chess's enclosure was empty again.

Before Ian could check to see if his heart was still beating, he heard a demanding meow. He spun.

From between a portable X-ray unit and a file cabinet holding a centrifuge, Chess's alien head poked out. Forgetting every protocol he'd ever written about touching lab subjects, Ian squatted down and picked up the cat. Gently he set Chess back in the enclosure and closed the glass door.

Chess butted the door with his head, rubbed his side against the glass, then lashed and crimped his harlequined tail.

The door clicked open. Ian caught it and pressed it shut. Frowning, he held his palm against it.

The cat walked in front of the door. It unlocked.

"What's happening?"

Ian then realized Chess's tail was at the same height as the retinal scanner. The scanners read blood-vessel patterns. Chess's blood vessels were close to the skin in his tail.

The scanner was reading his tail.

"Like zebra codes at the grocery store." Ian grinned. "It must be a simple default pattern."

He reached over and picked up a roll of masking tape, and ripped off a piece. Opening the door, he blocked Chess's escape with his stomach and covered the inner scanner with the tape. He closed the door again.

"Checkmate."

Nye Joell Hardy belongs to the taxon California coastalis var. geekosti; has sold a dozen stories; works as a food-safety specialist for a gigantic corporation that experienced some trauma with $E$. coli and spinach; and is actually a 'dog person'. 